\title{
Evaluation of Nutrient Digestion of Tamarind Seeds Spontaneous Bioconversion in Local Timor Pigs
}

\author{
Redempta Wea, I. G. K. Oka Wirawan and Bernadete B. Koten \\ Department of Animal Science, Kupang State Agricultural Polytechnic, Kupang 85011, Indonesia
}

\begin{abstract}
Tamarind seeds are one of the waste crops that were usually given to pigs and the use of spontaneous bioconversion can increase digestibility. The research objective was to evaluate nutrient digestibility spontaneous bioconversion of tamarind seeds at Timor Local Pig. The study was conducted from May to July 2017 in the Laboratory of Animal Production and Reproduction of Kupang State Agricultural Polytechnic. The study used local male pigs grower phase of 3-4 months old aged and used a randomized block design with four treatments and five replications, namely R0 = ration without bioconversion spontaneous tamarind seeds, R1 = rations containing $10 \%$ bioconversion spontaneous tamarind seeds, R2 = ration containing $20 \%$ bioconversion spontaneous tamarind seeds, R3 = ration containing 30\% bioconversion spontaneous tamarind seeds. The variables measured were dry matter digestibility, crude protein, crude fiber, and tannins. The results showed that spontaneous bioconversion of tamarind seeds affected significantly ( $p$ $<0.01)$ on dry matter digestibility, crude protein, ether extract, ash, and tannin digestibility but no effect $(p>0.05)$ on crude fiber digestibility. It was concluded that the use of tamarind seeds spontaneous bioconversion in livestock rations of local pigs Timor should be as much as $20 \%$.
\end{abstract}

Key words: Bioconversion, nutrient digestion, tamarind seed, spontaneous bioconversion, local Timor pig.

\section{Introduction}

The tamarind seed is a waste from processing industry of tamarind contents of $131.3 \mathrm{gkg}^{-1}$ crude protein nutrient, $67.1 \mathrm{gkg}^{-1}$ crude fibers, and 48.2 $\mathrm{gkg}^{-1}$ crude fats [1] and also contains many fatty tamarinds [2].

Despite good nutrient quality, the tamarind seeds also have a hard and non-destructive seed shell structure and have anti-nutrient substances in the form of tannins $56.2 \mathrm{gkg}^{-1}$ and antitrypsin activity of 10.8 $\mathrm{gkg}^{-1}$ are mostly located in testes or skins seeds [1]. These anti-nutrients will bind to the bonds of other compounds to form complex bonds making it difficult to decide or digest. Therefore, bioconversion processing technology is done spontaneously.

The results of Ref. [3] showed that there was an increase of nutrient content from tamarind that was not converted and spontaneously converted to 72

Corresponding author: Redempta Wea, S. Pt., MP, research field: pig production. hours of time, i.e. dry matter $89.89 \%$ to $90.02 \%$, gross energy $4,591.48 \mathrm{kcal} / \mathrm{kg}$ to $4,601.91 \mathrm{kcal} / \mathrm{kg}$, crude protein $16.65 \%$ to $17.66 \%$, crude fat $5.92 \%$ to $6.28 \%$, crude fiber $3.43 \%$ to $3.19 \%$, and ash $1.33 \%$ to $1.67 \%$. However, what level of optimal delivery in local pig ration to produce the best production performance should be known by knowing the nutrient digestibility.

\section{Materials and Methods}

\subsection{Bioconversion}

Tamarind seeds collected from the place of purchase, sorted from foreign objects, roasted to a fragrant and crushed shell, cultivation by soaking, soaking for \pm 24 hours ( $1 \mathrm{~kg}$ of acid seeds: 2 liters of water), slicing, wrapping in a plastic have been perforated, bioconversion \pm 72 hours, sun drying \pm 4 days, grinding into flour, and mixed in the ration according to treatment.

Research methods: CRD (completely randomized design) was employed in this experiment: $0,10,20$, and $30 \%$. Basic use of tamarind seed bioconversion is 
$20 \%$ as Refs. [4, 5]. The treatments were dosages of tamarind seed spontaneous bioconversion in rations: R0 = ration without bioconversion spontaneous tamarind seeds, $\mathrm{R} 1=$ rations containing $10 \%$ bioconversion spontaneous tamarind seeds, R2 = ration containing $20 \%$ bioconversion spontaneous tamarind seeds, R3 = ration containing $30 \%$ bioconversion spontaneous tamarind seeds. The treatments were repeated as many as five replicates which are fed with the same crude protein and energy is approximately $18 \%$ and 3,200 $\mathrm{Kcal} / \mathrm{kg}$ such as Table 1.

Measured variables were nutrient digestion dry matter, crude protein, crude fiber, ether extract, ash, and tannin. Dry matter, crude protein, crude fiber, ether extract, and ash were determined according to proximate analysis procedures [6]. Data were analyzed by analysis of variance of CRD DMRT (Duncan multiple range test) according to Steel and Torrie [7] which was performed to test the difference among treatments.

\section{Results}

Effects of treatments on dry matter, crude protein, crude fiber, ether extract, ash, and tannin digestion of tamarind seed spontaneous bioconversion in pig ration were illustrated in Table 2.

The result showed that dry matter digestibility significantly ( $p<0.01$ ) increased with increasing percentage of tamarind seed bioconversion in rations, especially at levels of $20 \%$ and $30 \%$, but there was no difference with ration digestion without the use of spontaneous bioconversion (R0).

The result of variance analysis showed that the spontaneous bioconversion of tamarind seed $(p<0.01)$ to the protein digestibility of pig livestock and protein digestibility in the use of spontaneous bioconversion of $20 \%$ tamarind seeds was similar to that of control ration than lower protein digestibility use of $10 \%$ and $30 \%$ bioconversion of spontaneous tamarind seeds. The digestibility of crude fiber rations is not affected $(p>0.05)$ by the use of tamarind seed spontaneous bioconversion.

Based on Table 2 it is also known that the crude fat and ash digestibility was affected $(p<0.01)$ by the use of spontaneous bioconversion of tamarind seed in the diet and there was no difference ( $p>0.05)$ crude fat content and ash between treatments of spontaneous $20 \%$

Table 1 Composition of research ration.

\begin{tabular}{lllll}
\hline \multirow{2}{*}{ Feed stuff } & \multicolumn{3}{c}{ Treatment feed composition (\%) } \\
\cline { 2 - 5 } & $\mathrm{R} 0$ & $\mathrm{R} 1$ & $\mathrm{R} 2$ & $\mathrm{R} 3$ \\
\hline Corn & 40 & 40 & 41 & 37 \\
Rice bran & 28 & 24 & 15 & 6.5 \\
Meat and bone meal & 3.5 & 6 & 7 & 7 \\
Soy bean meal & 12.5 & 10 & 8 & 5.5 \\
Cowpea seed & 14 & 8 & 7 & 30 \\
Tamarind seed spontaneous bioconversion & 0 & 10 & 20 & 1 \\
Pig mix & 1 & 1 & 1 & 1 \\
Vegetable oil & 1 & 1 & 1 & 88.10 \\
Nutrient of rations: & & & $3,254.11$ \\
Dry matter (\%) & 88.07 & 88.09 & 18.00 \\
Em (kcal/kg) & $3,221.17$ & $3,205.75$ & $3,238.2$ & 5.90 \\
Crude protein (\%) & 18.17 & 18.09 & 18.06 & 4.55 \\
Ether extract (\%) & 6.21 & 6.4 & 5.93 & 0.72 \\
Crude fiber (\%) & 6.32 & 5.87 & 4.5 & 0.64 \\
Ca (\%) & 0.41 & 0.69 & 0.78 & 0.48 \\
P (\%) & 0.75 & 0.8 & 0.73 & 0.19 \\
Lysine (\%) & 0.56 & 0.58 & 0.53 & 0.21 \\
Meth. (\%) & 0.25 & 0.24 & & \\
\hline
\end{tabular}


Table 2 Nutrient digestion of tamarind seed spontaneous bioconversion.

\begin{tabular}{lllll}
\hline Nutritive digestion & \multicolumn{4}{c}{ Dosage of tamarind seed spontaneous bioconversion (\%) } \\
\cline { 2 - 4 } & 0 & 10 & 20 & 30 \\
\hline Dry matter (\%) & $74.910 \mathrm{ab}$ & $69.798 \mathrm{~b}$ & $81.850 \mathrm{a}$ & $77.932 \mathrm{a}$ \\
Crude protein (\%) & $86.622 \mathrm{a}$ & $79.820 \mathrm{~b}$ & $86.275 \mathrm{a}$ & $79.522 \mathrm{~b}$ \\
Crude fiber (\%) & 37.544 & 46.551 & 55.831 & 48.783 \\
Ether extract (\%) & $90.550 \mathrm{a}$ & $86.110 \mathrm{~b}$ & $91.680 \mathrm{a}$ & $90.630 \mathrm{a}$ \\
Ash (\%) & $56.190 \mathrm{a}$ & $39.200 \mathrm{~b}$ & $63.530 \mathrm{a}$ & $59.420 \mathrm{a}$ \\
Tannin (\%) & $74.610 \mathrm{a}$ & $52.620 \mathrm{~b}$ & $58.160 \mathrm{~b}$ & $57.720 \mathrm{~b}$ \\
\hline
\end{tabular}

a, b, c Means on the same row with the same superscripts are not significantly different $(p>0.05)$.

*Bimoli oil that is marketed commercially in Indonesia.

and $30 \%$ with control rations without the use of tamarind seed spontaneous bioconversion. Similarly, tannin digestibility was effected $(P<0.01)$ by increased use of spontaneous bioconversion of tamarind seeds in rations and decreased digestibility compared to rations without the use of tamarind seed bioconversion.

\section{Discussions}

The increase in the digestibility of dry matter rations along with the increased use of tamarind seed bioconversion in the rations indicates that pigs have the ability to digest the spontaneous bioconversion of tamarind seeds by up to $30 \%$ in the rations. This shows that spontaneous bioconversion is able to provide good nutrient elements so easily digested by pigs. Dry matter degradation in this study is 69.80-81.85\% lower than result of research of Tualaka et al. [5] 83.28-86.53\%. This difference is due to the research using tempeh yeast as fermentor.

The digestibility of crude proteins that contain bioconversion of spontaneous tamarind seeds is lower than without spontaneous bioconversion but pigs can digest up to $20 \%$ in rations. The low level of protrein digestion is caused by the increasing use of spontaneous bioconversion of acid seeds in the ration, the higher the anti nutrient tannin that can bind protein, thus reducing its digestibility. Expressed so because tannins belonging to polyphenol compounds with characteristics that can form complex compounds with other macromolecules [8, 9]. However, protein digestibility in this study (79.522-86.275\%) was lower than that of Ref. [5], 90.97-92.99\%, due to differences in the use of fermenters.

The digestibility of crude fiber ration of pig livestock consuming the spontaneous bioconversion of tamarind seeds is higher than without the use of spontaneous bioconversion of tamarind seeds. This is because bioconversion causes the availability of nutrients is increasing so that the digestibilty increases. According to the statement of Ref. [10] fermentation can improve the digestibility of both protein and crude fiber digestibility.

Increasing the use of spontaneous bioconversion in rations also increases the digestibility of ether extract and ash and local Timorese pigs can use up to $30 \%$ in rations. This is because the activity of microorganisms in spontaneous bioconversion is able to break the complex bonds especially with the presence of tannins capable of binding carbohydrates and proteins to degradation as well as other nutrients so that the digestibility becomes increased.

The use of spontaneous bioconversion of tamarind seeds in the increasing ration causes lower tannin ration digestibility. This is because the higher the use of tamarind seed spontaneous bioconversion in the ration it will also increase the accumulation of tannin that causes decreased digestibility. This is in accordance with the statement of Refs. [11-13] that the presence of tannins in feed ingredients has a broad influence on livestock, namely reduced ration consumption, crude protein digestibility, and decreased the performance of 
monogastric livestock growth.

\section{Conclusions}

Increased use of tamarind seed spontaneous bioconversion in rations can improve the digestibility of nutrient rations and its use in recommended rations is as much as $20 \%$.

\section{Acknowledgments}

This experiment was funded by Hibah Bersaing Project 2016 from Directorate General of Higher Education, Department of National Education Republic of Indonesia.

\section{References}

[1] Panigrahi, S., Bland, B., and Carlaw, P. M. 1989. "The Nutritive Value of Tamarind Seeds for Broiler Chicks.” Animal Feed Science and Technology 22 (4): 285-93.

[2] Ishola M. M., Agbaji, E. B., and Agbaji, A. S. 1990. “A Chemical Study of Tamarindrus Indica (Tsamiya) Fruits Grown in Nigeria.” Journal of the Science of Food and Agriculture 51: 141-3.

[3] Wea, R., Koni, T. N., and dan Sabuna, C. 2015. "Optimum Time of Spontaneous Fermentation to Nutrient Value of Tamarind Seed as Alternative Feed.” Jurnal Veteriner 16 (1): 124-31.

[4] Wea, R., and dan Koten B. 2012. "Body Composition of Local Pigs Male Grower That Consumes Fermentation and the Use of Tamarind Seed in the Ration.” Jurnal Ilmu Ternak 13 (1): 8-12.

[5] Tualaka, Y. F., Wea, R., and Dan Koni, T. N. 2012. "Utilization of Fermented Tamarind Seeds with Tempe
Yeast (Rhyzopus Oligosporus) against Dry Matter and Crude Protein Digestibility of Local Pigs Ration.” Journal Partner. Kupang State Agricultural Polytechnic Tahun 19 (2): 152-64.

[6] AOAC. 1990. Official Methods of Analysis. 15th. Ed. Association and Official Analytical Chemist, Washington DC.

[7] Steel, R. G. D., and Torrie J. H. 1989. Principles and Procedures of Statistics Biometric Approach. 2nd Ed Translated by B. Sumantri. Gramedia Pustaka Utama, Jakarta.

[8] Waghorn, G. C., and McNabb, W. C. 2003. "Consequences of Plant Phenolic Compounds for Productivity and Health of Ruminants.” Proc. Nutr. Soc. 62: 383-92.

[9] Westendarp, H. 2006. "Effects of Tannins in Animal Nutrition.” Dtsch. Tierarztl. Wochenschr 113: 264-8.

[10] Sukaryana, Y., Atmomarsono, U., Yunianto, D. V., and Supriyatna, E. 2011. "Peningkatan nilai kecernaan protein kasar dan lemak kasar produk fermentasi campuran bungkil inti sawit dan dedak padi pada ayam pedaging.” Jurnal ITP 1 (3): 167-72.

[11] Smulikowska, S., Pastuszewska, B., Swiech, E., Ohtabiňska, A., Mieczkowska, A., Nguyen, V. C., and dan Buraczewska, L. 2001. "Tannin Content Affects Negatively Nutritive Value of Pea for Monogastric.” $J$. Anim. Feed Sci. 10: 511-23.

[12] Ferguson N. S., Bradford M. M. V., and dan Gous, R. M. 2002. "Diet Selection Priorities in Growing Pigs Offered a Choice of Feeds.” SA Anim. Sci. 32 (2): 136-43.

[13] Brus M., DolinŠek J., CenciČ A., and dan Škorjanc D. 2013. "Effect of Chestnut (Castanea Sativa Mill.) Wood Tannins and Organic Tamarinds on Growth Performance and Faecal Microbiota of Pigs from 23 to 127 Days of Age.” BAJAS Bulgarian Journal of Agricultural Science 19 (4): 841-7. 